\title{
Correction to: Using near-infrared spectroscopy to discriminate closely related species: a case study of neotropical ferns
}

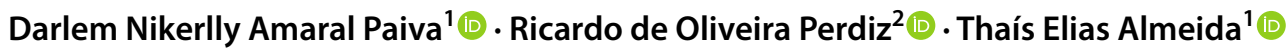

Published online: 20 April 2021

(c) The Botanical Society of Japan 2021

\section{Correction to: Journal of Plant Research https://doi.org/10.1007/s10265-021-01265-9}

In the original publication of the article, affiliation 2 was published incorrectly. The correct affiliation 2 should read as follows, "Instituto Nacional de Pesquisas da Amazônia, Programa de Pós-graduação em Ciências Biológicas (Botânica), Avenida André Araújo, 2936, Aleixo, Manaus, AM 69060001, Brazil".

In addition, ORCID number was not included to the second author "Ricardo de Oliveira Perdiz" and it is included in this correction.

Ricardo de Oliveira Perdiz's ORCID ID is 0000-0002-2333-6549.

The original article can be found online at https://doi.org/10.1007/ s10265-021-01265-9.

Darlem Nikerlly Amaral Paiva

nikerllyjc@hotmail.com; paivadarlem@gmail.com

Ricardo de Oliveira Perdiz

ricoperdiz@gmail.com

Thaís Elias Almeida

blotiella@gmail.com

1 Universidade Federal do Oeste do Pará, Programa de Pósgraduação em Biodiversidade, Rua Vera Paz, s/n (Unidade Tapajós) Bairro Salé, Santarém, PA 68040-255, Brazil

2 Instituto Nacional de Pesquisas da Amazônia, Programa de Pós-graduação em Ciências Biológicas (Botânica), Avenida André Araújo, 2936, Aleixo, Manaus, AM 69060-001, Brazil
Publisher's Note Springer Nature remains neutral with regard to jurisdictional claims in published maps and institutional affiliations. 